\title{
A Happy Ending but an Unhappy Fate: Marguerite Duras' La Vie tranquille
}

\author{
Noelle English
}

Published online: 7 July 2009

(C) Springer Science+Business Media B.V. 2009

\begin{abstract}
This article begins by analysing the various critical reactions to Duras' (La Vie tranquille, Gallimard, Paris, 1944) second novel, La Vie tranquille and seeks to find a reason for its lack of critical success. Through looking at Duras' personal situation at the time of this novel's conception, it finds that the deaths of both her brother and her first child influence not only the representation of grief in the novel, but also its various attempts to envisage optimism, both through the voice of its narrator and through its use of myth and metaphor. In the light of Miller's (PMLA 96(1):36-48, 1981) interpretation of Genette's (Figures II, Seuil, Paris, 1969) theory of 'vraisemblance', it finds that the common criticism of the novel on the grounds of its plausibility actually highlights why this is a highly significant novel in terms of feminist writing and in the assessment of Duras' career.
\end{abstract}

Keywords Duras · La Vie tranquille $\cdot$ Miller $\cdot$ Genette

C'est un chef d'œuvre et un chef d'œuvre méconnu, sinon inconnu. Le second roman de M. Duras dans l'ordre chronologique, il explique et annonce la suite de l'œuvre, premier volet d'un grand ensemble. Toute lecture sérieuse des livres de cet auteur doit commencer par ce roman-là.

(Berger 1960, p. 210).

In spite of Yves Berger's praise of Marguerite Duras' second novel, La Vie tranquille (1944), it is a work that remains often overlooked and generally undervalued in the assessment of her auvre. This is in no small part due to the author herself who was keen to turn away from a book that was written during a deeply traumatic period of her life. (The months that preceded the publication of $L a$

\footnotetext{
N. English $(\bowtie)$

School of Languages and Literature, University of Ulster, Coleraine, Co. Derry BT52 1SA,

Northern Ireland, UK

e-mail: noelle.english@gmail.com
} 
Vie tranquille saw not only the stillbirth of the author's first child but also the death of her brother, Paul. $)^{1}$ This rejection of the book by its author has been repeatedly compounded by mixed critical reception to its form and fictional credibility, with the result that it is frequently ignored. It is sometimes commented on, but rarely considered, as Yves Berger suggests above, as an crucial work in terms of the development of her writing. This study seeks to revisit this novel, looking not only at the work itself, but also at its critical reception in an attempt to evaluate its integral significance as a work of fiction, and also its position in relation to the rest of Duras' career.

In the brisk linear narrative of the opening section of La Vie tranquille, we are introduced to its heroine and narrator, Françou Veyrenattes. Possessed of a singularly pragmatic view on life, Françou describes her life with her elderly parents, her beloved brother, Nicolas his wife Clémence and his baby son Noël, his friend, Tiène, and her despised uncle Jérôme, on the family homestead, Les Bugues in rural France. Early in the novel, we are told that the family had been forced to move from their home in Belgium following a financial scandal that they collectively blame on the uncle, Jérôme. The purge of years of bitterness takes place before the opening of the novel as Nicolas (having been told by Françou of an affair between his wife and Jérôme) attacks the uncle and fatally wounds him. Following the prolonged suffering and eventual death of the uncle, Françou's sister-in-law leaves Les Bugues and puts her child in Françou's care, a situation that allows for scenes of considerable pathos where Françou impotently plays the role of nursing mother. This expression of maternal desire is further compounded by Françou's protective instinct towards her brother and her sexual attraction to his friend, Tiène, as the first section of the novel becomes a complex criss-cross of lust that is fuelled largely by the capricious desires of Nicolas' girlfriend, Luce Barrangues. Following Luce's ultimate rejection of him, Nicolas is overwhelmed by depression and the first section of the novel ends with the discovery of his suicide.

In the second section of the novel, we see a shift in tone and pace as Françou takes a solitary trip to the seaside. During this period of solitude, Françou takes the time to evaluate her identity while lying in her hotel room, and swimming in the sea. In the final section of the novel, Françou returns to Les Bugues in a haze of fever. On arrival at Les Bugues, she meets with the farmhand Clément, who relates how her parents are caught in a routine of grieving that is increasingly characterised by inertia and senility. He also tells her that Luce calls to the house every evening to visit Tiène. Rather than going to see her family, Françou prefers to go to Clément's hut where she spends 3 days sleeping through her fever. On her recovery, she returns to the farmhouse, and in the few closing pages of the novel, we see her tending to her parents, telling them of her imminent marriage to Tiène, and the

\footnotetext{
1 Adler (1998, p. 215) testifies to the author's dismissal of the book after its publication, "Marguerite dira que ce livre est tombé d'elle même. Elle l'oublia rapidement, ne souhaitant même plus d'en parler." In an interview with Brée (1972, p. 407) she dismisses her early novels, "What I have explored in my first books no longer interests me". In her interview with Gauthier (1974, p. 13), she again directs the conversation away from her early novels: "Il y a toute une période où j'ai écrit des livres, jusqu'à Moderato Cantabile, que je ne reconnais pas."
} 
prospect of a new grandchild. The novel closes with Françou and Tiène lying together in bed, in an optimistic ending.

One of the most common charges made against the novel is on the basis of the voice of its narrator. Jean-Luc Seylaz criticised.

l'articulation assez maladroite du plan de la psychologie et du plan de la durée. (1963, p. 15)

a sentiment that was echoed by Yvonne Guers-Villate, when she found "une surabondance d'éléments dramatiques" (1985, p. 30) and writes,

ses analyses introspectives ne sont guère en accord avec la condition de l'héroïne, petite paysanne sans instruction. (ibid.)

This impression had also been expressed by Alfred Cismaru in 1971, in an article that introduced the novel to an American audience,

it seems that credibility suffers to a degree when the sagacity of the writer is bestowed upon a personage like Françou. (1967, p. 32)

Thus it would seem that this novel's credibility, or more precisely, its plausibility has been the greatest concern of its critics. Miller (1981) addresses the issue of plausibility in women's fiction, using as theoretical basis Genette's (1969) study of vraisemblance in Figures II. Translating 'vraisemblance' as plausibility, she discusses Genette's theory of the plausibility of fiction being based upon the expectation that a character will behave according to 'an approved maxim'. In applying this theory to La Princesse de Clèves, she writes,

If no maxim is available to account for a particular piece of behaviour, that behaviour is read as unmotivated and unconvincing. (...)

To build a narrative around a character whose behaviour is deliberately idiopathic, (...) is not merely to create a puzzling fiction but to fly in the face of a certain ideology (of the text and its context), to violate a grammar of motives that describes while prescribing, in this instance, what wives, not to say women, should or should not do. (Miller 1981, p. 38)

If the behaviour of female characters is prescribed by what Miller calls a 'grammar of motives' then the behaviour of Françou would seem to be further circumscribed by her social class. In reading the above criticisms, we see that the psychological profile in itself is not so much criticised as the application of this profile to an uneducated farmer's daughter. This criticism would seem to be untenable, however, given that Françou's narrative remains consistently bound, throughout the novel, by the parameters of her experience. From her petulant defence of her part in the assault on Jérôme,

J'ai dit à maman que Nicolas s'était battu avec Jérôme, à cause de Clémence, et aussi à cause de tout ce qui couve entre nous depuis toujours. Je n'ai rien aggravé, Jérôme a dépensé toute notre fortune. Il est cause que Nicolas n'a jamais pu faire d'études, ni moi non plus. Nous n'avions jamais eu assez d'argent pour quitter les Bugues. C'est aussi pourquoi je ne suis pas encore 
mariée. Nicolas s'est marié avec Clémence. Elle est ma sœur de lait, mais tout de même, elle est notre servante, et elle est laide et bête. Il y aura deux ans aux vendages, il l'a mise enceinte et il a bien été obligé de l'épouser. Si Nicolas avait pu connaître d'autres filles, il n'aurait pas fait cette sottise. (La Vie tranquille 15)

to her delicate observation of the changing seasons,

Septembre jaunissant est arrivé avec son odeur de feu éteint. (ibid. 86)

we see that Françou is an affective narrator who is reactive to her social and physical environments. This is particularly true of the first section of the novel, that is concerned primarily with the domestic complexities of Les Bugues and is charged with foregrounding the circumstances that allow for Françou's self-discovery in sections two and three.

This self-discovery is elicited by Françou's grief following Nicolas' suicide at the end of the first section, a death that acts as a pivot upon which the tone and focus of the novel changes completely. Once removed from her home environment, Françou is given the time to analyse previous events and she does this in repetitive cycles of thought that are formed around key themes: Nicolas, Tiène and her own existence. Once again, we see that her thoughts are rooted in her environment, as we see her use the sea and her own body as key metaphors in externalising the various crises and conflicts that are part of the grieving process. ${ }^{2}$ On arrival at the room of her pension, for example, the paranoia and insecurity that characterises the onset of the grieving process is seen through a literal contemplation of the self,

J'étais couchée lorsque je me suis aperçue couchée dans l'armoire à glace; je me suis regardée. Le visage que je voyais souriait d'une façon à la fois engageante et timide. Dans ses yeux, deux flaques d'ombre dansaient et sa bouche était durement fermée. Je ne me suis pas reconnue. Je me suis levée et j'ai été rabattre la porte de l'armoire à glace. Ensuite, bien que fermée, j'ai eu l'impression que la glace contenait toujours dans son épaisseur je ne sais quel personnage, à la fois fraternal et haineux, qui contestait en silence mon identité. Je n'ai plus su ce qui se rapportait le plus à moi, ce personnage ou bien mon corps couché là, bien connu. Qui étais-je, qui avais-je pris pour moi jusque-là? Mon nom même ne me rassurait pas. Je n'arrivais pas à me loger dans l'image que je venais de surprendre. Je flottais autour d'elle, très près, mais il existait entre nous comme une impossibilité de nous rassembler. Je me trouvais rattachée à elle par un souvenir ténu, un fil qui pouvait se briser d'une seconde à l'autre et alors j'allais me précipiter dans la folie. (La Vie tranquille 122-123).

While the knowing reader may find comparisons with Freudian theory here, the narrative voice retains the same simplicity and directness of the first section of the novel and does not compromise the identity of heroine. The expression of grief is

\footnotetext{
${ }^{2}$ For a detailed analysis of the process of grieving, see Klein (1977) Love Guilt and Reparation.
} 
maintained through not only her consideration of her brother, but also through her self-consciousness regarding her shifting thoughts and emotions.

La nuit, quand je ne dors pas, je pense que Nicolas est mort, qu'il est en ce moment dans le petit cimetière des Ziès, pour toujours. Que moi je suis couchée dans ce lit, encore vivante pour un temps indéterminé. Mais ces pensées-là sont toujours les mêmes et l'on s'en distrait facilement. (ibid. 127-128).

This willingness to abandon lines of thought, coupled with the repetitive cycles of these thoughts introduce a very different kind of narrative in section two, one that mirrors the grieving process, as Françou attempts to come to terms with the reality of a world in which her brother exists only as a memory. As this process develops, we see Françou come to reflect on herself and eventually rejoice in her own existence.

J'éprouve la lassitude fière d'être née, d'être arrivée à bout de cette naissance. Avant moi, il n'y avait rien à ma place. Maintenant, il y a moi à la place de rien. (ibid. 143)

This celebration of life is coupled with a remarkable contemplation of her femininity, again based on a simple observation of her body,

Alors je pense que je suis une femme. Que je suis vivante en femme, pas en n'importe quoi, en femme seulement. Je n'oserai pas affirmer que jusqu'ici je n'espérais pas être également vivante en d'autres espèces. Courir un jour sur la colline comme la chienne de Clément. Étendre un jour mes branches comme le magnolia de la cour. (...) De quelle hypocrisie je suis ! On ne voit rien du gouffre qui est là, entre mes jambes. Celui qui le découvrirait croirait qu'il vient de s'ouvrir sous lui, par lui. Il est perfidie et innocence. Il est une chose qui toujours attendait celui qui vient, qui n'est rien qu'un aboutissement pour autre chose. Or, le fond de ce gouffre est en même temps le refuge, le seul refuge contre le ciel et l'une des murailles les plus dernières du monde. Je n'y peux rien. Je ne suis rien auprès de cela. Mais cela est en moi, accroché en moi, se devine dès ma figure.

Je l'oublie facilement, mais il reste lié à la pensée de Tiène. Tiène est l'homme que j'aime. (ibid. 128-129)

It is precisely the anchoring of this narrative in physical references that maintains the voice's authenticity, while fully exploring the scale of the character's experience, and that also offers us a indication of developments in later work through the meditation upon the sea, and its use as both death and maternal metaphor,

La crête de la vague vous gifle, les yeux sont deux trous brûlants, les pieds et les mains sont fondus dans l'eau, impossible de les soulever, ils sont liés à l'eau avec des nœuds, perdus, et pourtant voulant se retrouver comme ceux de l'innocence même (eux qui vous ont servi à faire vos pas fuites, vos larcins, ils crient : je n'ai rien fait, je n'ai rien fait...). Il fait très noir, on ne voit plus rien que du calme dans des lueurs. On est les yeux dans les yeux pour la première fois avec la mer. On sait avec les yeux d'un seul regard. Elle vous veut tout de 
suite, rugissante de désir. Elle est votre morte à vous, votre vieille gardienne. C'est donc elle qui depuis votre naissance vous suit, vous épie, dort sournoisement à vos côtés et qui maintenant se montre avec impudeur, avec ces hurlements? (ibid. 144-145)

The significance of this passage in terms not only of Duras' career, but also in relation to feminist theory regarding the maternal relation and its significance to female identity, is crucial. This passage represents not only Duras' most overt association between two crucial motifs of her career, (i.e. la mer and la mère) but articulates the complex layering of desire and fear between mother and daughter that would be explored in feminist debate of the 1970s. ${ }^{3}$ The parallels with later feminist theory do not end there. In the final section of the novel (which is most commonly dismissed) we see an abundance of lyricism and myth metaphors that serve to reconstitute the psychological integrity and strength of the heroine, features that again anticipate subsequent work in feminism.

The final section of the novel is divided into two subsections. The first of these subsections features Françou's walk from the train station to Les Bugues on a wet night. Here we see her repeated contradictions in expressing her emotions and desires, as she reflects self-consciously upon her thoughts:

Quand je me remets à penser à quelque chose, je pense aussi que je recommence à y penser. (ibid. 195).

This contrast between a seemingly unregulated flow of thought and the conscious awareness of this thought, reflects the general contrast between the overt chaos that is evident through the stream of consciousness and the underlying metaphorical and thematic structure which controls the progression and conclusion of Françou's development. This structure is echoed, at the opening of this section, through Françou's concentration upon the rhythm of her footsteps,

Deux par deux, ou trois par trois, ou quatre par quatre. On ne sait pas quel est le pied qui suit l'autre. Suivant que je pense au gauche ou au droit, c'est le gauche ou le droit. Il aurait fallu savoir par quel pied j'ai commencé à marcher étant bébé. (ibid. 196)

This concept of returning to one's origins in search of knowledge again prepares us for the emphasis upon a movement towards the fundamental and primitive values of myth, where birth and death become major metaphors for human development; the use of the word 'bébé' further stresses this notion. This presentiment of a new beginning is accompanied by the ability to forget, "dommage d'oublier tout et tant mieux" (ibid) and thereby to clear her head : "Ma tête est fraîche, vide tout à coup" (ibid). As is characteristic of this work and particularly this section, however, this optimism is immediately followed by a contradicting emotion of despair “(...) je ne serai jamais plus à mon aise nulle part (...)" (ibid). This confusion is gradually accepted by Françou, however, as we come towards the conclusion of this subsection:

\footnotetext{
${ }^{3}$ See for example Cixous (1977), Irigaray (1979), and Kristeva (1983).
} 
Le désordre. L'ordre aussi, elles viennent chacune à leur tour on ne peut pas dire le contraire, par exemple : j'ai choisi de rester aux Bugues pour toujours. Aussitôt après, il n'y a pas un coin du monde où je ne voudrais pas ne pas aller. (ibid. 199)

as she accepts the alternating patterns of thought which appear as dichotomies, like the footsteps which we have seen earlier. Through this observation, we see how Françou accepts the existence of dichotomy and paradox within her own consciousness. As this section comes to a close, we see a more and more determined emphasis on optimism "On l'aura la vie tranquille" (ibid. 203). This phrase is repeated over and over, as Françou insists upon optimism, in spite of her repeated reflections on Nicolas' death.

Rather than going to join with her family when she returns to Les Bugues in section three, Françou goes to Clément's hut where she sleeps through her fever for 3 days and three nights which, in itself reflects the Christian motif of resurrection. But the presence of and emphasis on the role of Clément in this homecoming would suggest stronger parallels with the story of Odysseus. On Odysseus' homecoming, he is welcomed first by his loyal swineheard, Eumaeus, who relates to him the turmoil which has gripped his household in his absence; his wife, Penelope, is inundated with suitors who believe her husband to be dead, and his son, Telemachus is unable to protect the house from them. Eumaeus despairs at this situation, recounting to Odysseus (who is in disguise) the virtues of his absent master. Rather than returning to his house immediately, Odysseus sleeps by the fireside with his servant. Eventually, Odysseus reveals his identity to Eumaeus and his son before returning to test and thereby assert Penelope's fidelity, rid the house of the suitors and assume his position as head of the household.

Françou's arrival at Les Bugues and her decision to stay with Clément both recall the encounter between Odysseus and Eumaeus. As is the case with Eumaeus, Clément relates not only his acute understanding of the domestic situation, but through his own clear virtue and steadfast loyalty represents the anticipation of a restoration of stability. When Françou meets Clément, he tells her of Luce's regular visits to Tiène, she does not, however, feel threatened by Luce's presence; she even admires the extent of Luce's determination and desire which is almost heroic in its dramatic extremes.

Je la vois : enchâssée sous un grand capuchon de pluie, toujours plus belle, qui vient chercher Tiène. Tiène malgré la pluie, le vent, la honte. Ce qu'elle doit avoir honte. Mille montagnes ne l'arrêteraient pas. Y crèverait sa jument, y vieillirait-elle, ne vieillirait-elle que pour y arriver, rien ne l'arrêterait sauf moi. (ibid. 210)

Luce's passion only serves to highlight the superiority of Françou, who knows that on her return, Luce will be forced to leave.

Luce. Ce qu'elle doit être effrayée par l'idée de mon retour. Ce qu'elle doit être devenue timide tout à coup devant elle-même qui se voit revenir aux Bugues et s'asseoir dans l'atelier avec les parents de Nicolas. (ibid. 211) 
The sense of superiority which Françou expresses here, is in contrast to her earlier admiration for Luce's slender, feminine body which contrasts with her own strong, muscular figure. Françou's confidence here is the result of her personal selfevaluation and development in section two, that is here further underlined by mythical undertones. On her return, Tiène, like Penelope confirms his fidelity, which is born of a devotion that asserts the superior character of the heroine.

Je ne lui ai rien demandé. Il m'a dit qu'il n'avait même pas pu toucher Luce Barragues parce que c'était de moi qu'il avait envie. (ibid. 217)

This depiction of Tiène as the faithful and patient spouse represents a remarkable role reversal that, through his submissiveness, serves to further assert the strength of the heroine. When she does return, Françou notes that she will become mistress of the household and that Tiène will have to recognise this:

(...) j'ai aperçu Tiène dans la cour. Il parlait aux métayers et vraisemblablement leur donnait des ordres. Il était vêtu d'un costume sombre et paraissait plus petit que lorsque je l'avais quitté. (...) Je me suis demandé pourquoi il donnait des ordres aux métayers. Il les avait choisis et installés alors que c'était moi qui aurais dû le faire puisque j'étais la seule maîtresse des Bugues. (ibid. pp. 213-214)

This myth structure allows for a considerable level of superiority in the narrative voice, and facilitates the assertion of the heroine at a metaphorical level. When Françou, then, announces that she is to marry Tiène, it is very much a statement of triumph and represents the heroine claiming her place as matriarch, in a complete reworking of the classical patriarchal myth format of the returning hero.

This manipulation of not only myth, but also the entire narrative format of the novel in articulating the deconstruction and reconstitution of the heroine represents an audacious venture by Duras. Through a transmutation from linear to cyclical and subsequently metaphorical narrative, Duras moulds the novel to achieve the fullest possible psychological exploration of its heroine, and in so doing challenges the limits of the reader's expectations regarding the form and direction of the text. But this degree of experimentation with the narrative form has proved to be a step too far for Duras' critics. Tison-Braun (1984, p. 24) echoes the criticism by Seylaz and Guers-Villate: 'la fin du récit est hâtive et peu claire: retour, maladie, jalousie, puis une conclusion somme toute optimiste, mais insatisfaisante." The transition between narrative styles, not twice but three times in the novel, breaks code of silent adherence to genre that, as Genette points out, is central to plausibility.

The relationship between a plausible narrative and the system of plausibility to which it subjects itself is ... essentially mute: the conventions of genre function like a system of natural forces and constraints which the narrative obeys as if without noticing them, and a fortiori without naming them. (Miller 1981, p. 38)

Through requiring the reader to adjust not once but twice to a significant change of narrative, Duras disobeys the 'natural forces and constraints' of fiction, thereby unsettling and ultimately confusing the reader. Yet it is precisely this struggle to 
innovate in and thereby lay claim to a narrative form that will articulate the triumph of a female character within a traditional domestic context which represents the most significant parallel with a feminist theory of writing, particularly Luce Irigaray's theory of mimesis.

Jouer de la mimesis, c'est donc, pour une femme, tenter de retrouver le lieu de son exploitation par le discours, sans s'y laisser simplement réduire. C'est se resoumettre-en tant que du côté du 'sensible', de la matière-à des 'idées', notamment d'elle, élaborées dans/par une logique masculine, mais pour faire apparaître, par un effet de répétition ludique, ce qui devait rester occulté: le recouvrement d'une possible opération du féminin dans le langage. (Irigaray 1979, p. 74)

From its linear opening section, to the metaphor of its closing pages, La Vie tranquille would seem to embody precisely the 'operation' of the woman writer within the history of prose and her subversion of that form to articulate a female logic that, as we have seen, is derived from a gender specific physical analysis of the self. Only once the narrative form has been adapted to this purpose, is the scope provided for the depth of psychological evaluation achieved in La Vie tranquille.

Returning to the criticism of the 'sagacity' of the narrative voice, it seems, I would suggest, that the plausibility of Françou's self-expression rests not so much on what she says, or indeed how she says it, but that she says so much. In a fervent effort to achieve as thorough a portrait as possible of the heroine, the narrative both self-consciously inscribes a series of psychological reference points, and also through its meditation upon the body, anticipates an entire field of debate on female identity and expression. The idiopathy, to use Miller's term, of Françou's behaviour is that she is given the time and space to deconstruct and explore all facets of her personality, and she does so with great vigour. Although it is well foregrounded in the text, the motives of the character in speaking about her maternal, sexual and intellectual drives in the way she does is questioned, precisely because it is an unprecedented level of female expression, an 'action without a maxim'.

This portrait of the female condition, however, represents not only erotic and maternal drives. La Vie tranquille both converges with and diverges from Miller's theory of women's fiction when it deals with the issue of power. In discussing Freud's theory of male versus female fantasy, Miller finds that women's writing is often found to be unsatisfactory because it expresses the 'ambitious wish' that Freud found is essentially a male fantasy.

Women writers, (...) in contrast to lady novelists, are writers whose texts would be "among the finest" (...) and for whom the "ambitious wish" (...) manifests itself as fantasy within another economy. In this economy, egotistic desires would assert themselves paratactically alongside erotic ones. The repressed content, I think, would be, not erotic impulses, but an impulse to power: a fantasy of power that would revise the social grammar in which women can participate only as objects of circulation. (Miller 1981, p. 46)

But while Miller finds that this ambition is expressed in women's fiction through a silent refusal to conform to stereotype, Françou's impulse to power is a much more 
overt and uncompromising one. From the way in which she antagonises her brother's anger at the outset of the novel, (thereby destroying her uncle) to her increasing control over her family, Françou is clearly the creator of her own destiny. In establishing her succession to her parents, and declaring her matriarchal authority, Françou not only wants it all, but gets everything that she wants, and this is perhaps where the critical dissatisfaction with the novel's credibility is also rooted. Not only is the second section of the novel devoted to a complete psychological evaluation of the heroine, but through the deconstruction and the succeeding fortification of the heroine, she is, by the time she re-enters the social world at the end of the novel, virtually invincible. It is the masculine power fantasy fulfilled in the most overt way imaginable, and a fantasy that involves a remarkable reworking of a patriarchal myth.

But while Miller finds the "master-key that will fix all cases" rejected in women's fiction, it is very much in evidence at the end of La Vie tranquille. And it is the fact that Duras adopts so overtly the conventions of the masculine heroic tradition that makes this novel so fascinating. Because, while Miller assures us that

the plots of women's literature are not about 'life' and solutions in any therapeutic sense, nor should they be (...) (ibid)

La Vie tranquille, precisely because it is a response to crisis, is a therapeutic novel. It is impossible to ignore the personal circumstance of the author as she creates a character who is so determinedly optimistic as Françou. And this is where the significance of the novel in terms of Duras' career can be seen most clearly. Through the crisis at the centre of this novel, we see the first appearance of major issues of her later writing, i.e. the maternal relation, sibling love and separation, but in this context the effort to resolve these issues and achieve a condition of not only acceptance, but also of happiness. It is precisely in this movement towards resolution that these various issues are explored and explained to their fullest extent, with the result that this novel represents an invaluable foundation for the critical evaluation of these themes and motifs in later writing.

\section{References}

Adler, L. (1998). Marguerite Duras. Paris: Gallimard.

Berger, Y. (1960). Marguerite Duras. In B. Pingaud (Ed.), Écrivains d'aujourd'hui-1940-1960 (pp. 207-214). Paris: Grasset.

Brée, G. (1972). Interview with Marguerite Duras. Contemporary Literature, 13(4), 401-422.

Cismaru, A. (1971). Marguerite Duras. New York: Twayne.

Cixous, H. (1977). La Venue à l'écriture. In: H. Cixous, M. Gagnon, A. \& Leclerc (Eds.), La Venue à l'écriture. Paris: Union Générale d'Éditions. (This article was reprinted in Cixous, H. (1986) Entre l'Ecriture (pp. 9-69). Paris: Des Femmes).

Duras, M. (1944). La Vie tranquille. Paris: Gallimard.

Gauthier, X. (1974). Les Parleuses. Paris: Éditions de Minuit.

Genette, G. (1969). Figures II. Paris: Seuil.

Guers-Villate, Y. (1985). Continuité/Discontinuité de l'Euvre durassienne. Bruxelles: Éditions de l'Université libre de Bruxelles.

Irigaray, L. (1979). Et l'une ne bouge pas sans l'autre. Paris: Éditions de Minuit. 
Klein, M. (1977). Love, guilt and reparation. New York: Dell.

Kristeva, J. (1983). Histoires d'Amour. Paris: Denoël.

Miller, N. K. (1981). Emphasis added: Plots and plausibilities in women's fiction. PMLA, 96(1), 36-48.

Seylaz, J. L. (1963). Les Romans de Marguerite Duras: Essai sur une Thématique de la Durée. Paris: Archives des Lettres Modernes.

Tison-Braun, M. (1984). Marguerite Duras. Amsterdam: Rodopi. 